prof.dr hab.inz. Jerzy Madej

dr hab. inz. Marian Medwid

Instytut Pojazdów Szynowych ,TABOR”

\title{
Nowa koncepcja przestawczego układu biegowego pojazdu szynowego dla różnych szerokości toru w zarządach UIC - ОСЖД
}

\begin{abstract}
$W$ referacie omówiono przestawny układ biegowy pojazdu szynowego dla różnych rozstawów szyn. Jest nim zestaw odpowiednio poszerzonych kót, pozbawionych obrzeży, stowarzyszony nieodtacznie z nastawnym zespołem dwóch ,obcych" rolek prowadzacych, przeznaczony do ruchu kolejowego pomiędzy dwoma sieciami transportowymi wschodniej Europy UIC - ОСЖД. Celem głównym rozwiqzania jest ułatwienie przekraczania granicy bez wymiany wózków.

Odpowiednio poszerzone pierścienie biegowe kót nośnych obejmuja obydwie szerokości toru w sqsiadujacych zarzqdach kolejowych. Techniczna zasada nowej koncepcji została przedstawiona na rysunkach $i$ odpowiednio skomentowana. W referacie poświęcono należyte miejsce zagadnieniu bezpieczeństwa przed wykolejeniem. Znaczqca (stowarzyszona) korzyścia omawianego rozwiazania jest znacznie niższy koszt reprofilacji zarysu kót nośnych w porównaniu do korekcji kót zestawów klasycznych po porównywalnym przebiegu eksploatacyjnym.
\end{abstract}

\section{Racjonalny zarys współpracy koła i szyny}

W światowej kolejowej technice taborowej znane są liczne rozwiązania konstrukcyjne tzw. przestawnych zestawów kołowych w układach biegowych pojazdów szynowych przeznaczonych do ruchu w obrębie zarządów kolejowych o różnych szerokościach toru. We wszystkich tych rozwiązaniach zestawy kół mają odpowiednio uprofilowane, rozsuwane koła klasyczne, z własnymi obrzeżami. Zestawy dla transportu przestawczego z kołami rozsuwanymi są pod względem mechanicznym bardzo złożone, kosztowne i przeznaczone głównie dla wagonów pasażerskich; nie mogą być stosowane w lokomotywach.

Nowa koncepcja techniczna budowy szczególnie prostego zestawu kół dla transportu przestawczego ma zestawy z kołami nie rozsuwanymi. Koła biegowe takich zestawów mają być odpowiednio poszerzone i pozbawione obrzeży, zaś rozsuwane są jedynie obce obrzeża rolkowe. Dodatkową zaletą prezentowanego rozwiązania jest znaczące zmniejszenie kosztów reprofilacji eksploatacyjnie zużytych bieżni kół, gdyż „obce” obrzeża są znacznie mniejsze i tańsze od kół nośnych oraz mogą być łatwo wymieniane.

Wymiarowo bliski rozstaw szyn UIC - ОСЖД $(42,5 \mathrm{~mm})$ we wspólnym obszarze skrajni taboru może być obsługiwany przez powszechnie aprobowany zestaw kół z poszerzonymi pierścieniami biegowymi 1 pozbawionymi obrzeży, oraz zespół „obcych”, rolkowych, rozsuwanych obrzeży bezpieczeństwa 2.

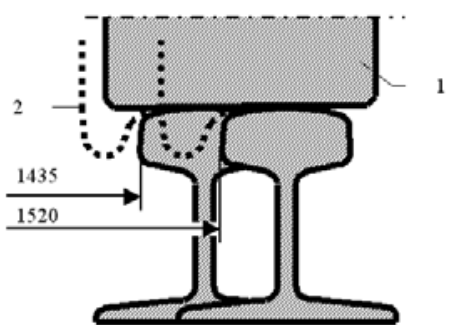

Rys. 1. W sąsiadujacych zarządach UIC - ОСЖД jednostronna różnica położeń szyn $\mathrm{w}$ stosunku do osi toru wynosi $85 / 2=42,5$ $\mathrm{mm}$

Jeżeli na rysunek 2 spojrzymy w pozaemocjonalnym świetle nauki i postępu, to racjonalną budowę zarysu współpracy koła z szyną powinny określać dwa bezwzględne czynniki techniczne:

- bezdyskusyjny pewnik, że podstawowe prowadzenie zestawu w torze dokonuje się za pomocą adhezyjnych sił podłużnych, oraz

- obrzeża biegowych kół zestawu spełniają funkcję zabezpieczająca przed zejściem $\mathrm{z}$ toru zgodnie $\mathrm{z}$ kryteriami bezpieczeństwa wyznaczonymi metodami naukowymi, jak na przykład kryterium Nadala [1].

$$
\frac{Y}{Q}=\frac{\operatorname{tg} \gamma-\mu}{1+\operatorname{tg} \gamma}
$$

gdzie:

$Y$ - siła boczna skierowana zgodnie $\mathrm{z}$ kierunkiem osi zestawu,

$Q$ - pionowy nacisk koła na szynę, 
$\gamma$ - kąt styku koła z szyną,

$\mu-$ współczynnik tarcia w punkcie styku.

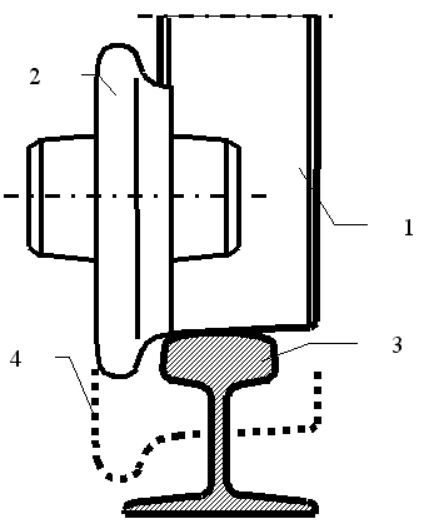

Rys. 2. Zasada współpracy części biegowej nieklasycznego koła zestawu 1, wyposażonego w obce obrzeża rolkowe 2 , z szyną 3 , zapewniająca realizację profilu klasycznego 4, widziana w płaszczyźnie pionowej pojazdu zgodnie z kierunkiem osi tor

Wyżej wymienione czynniki pozwalają na budowę technicznie racjonalnego zestawu nieklasycznego, z rolkowymi obrzeżami spełniającymi kryterium (1).

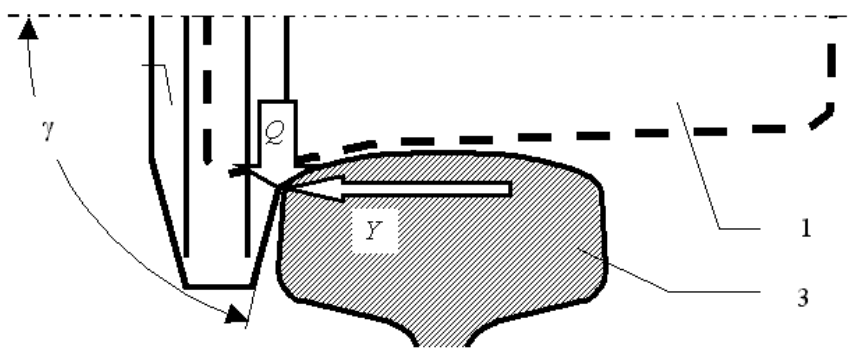

Rys. 3. Praca obcego obrzeża $2 \mathrm{w}$ warunkach nabiegania na szynę

\section{Elementarna zasada budowy podwozia pojazdu}

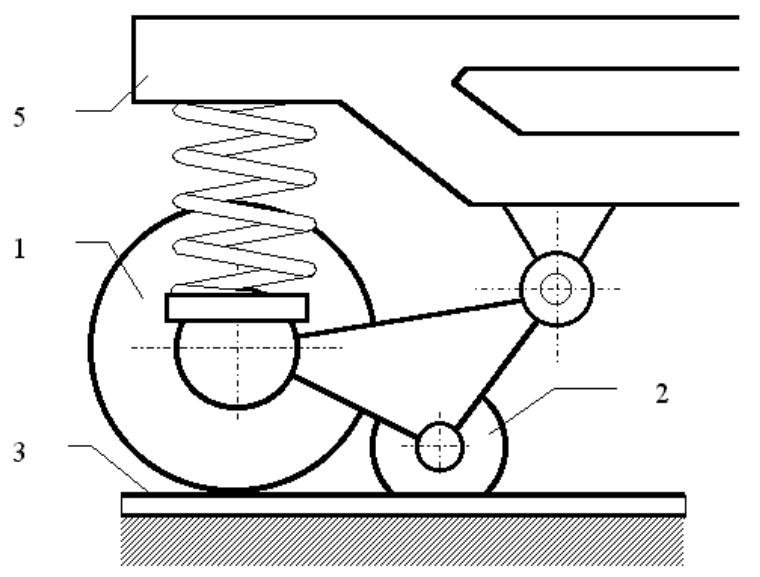

Rys. 4. Obce obrzeże rolkowe 2 powinno być osadzone po wewnętrznej stronie szyny 3 , pod ramą 5 pojazdu możliwie blisko koła biegowego 1

\section{Konstrukcyjna elastyczność budowy zestawu}

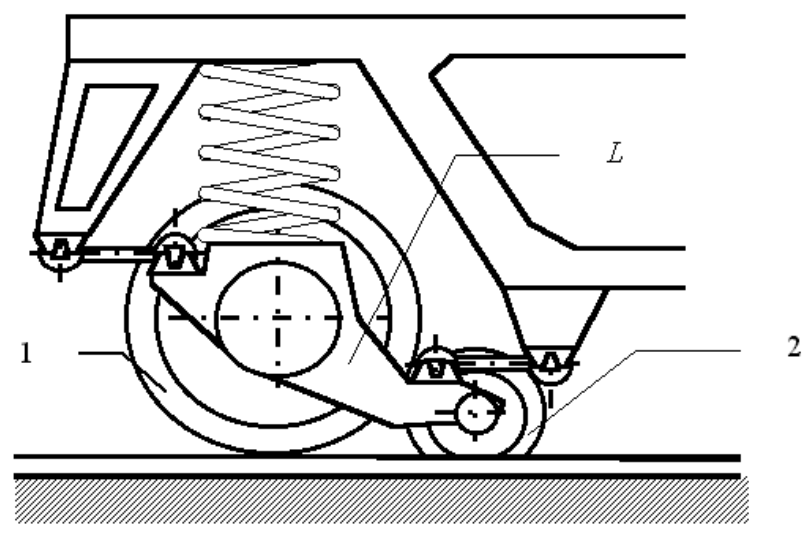

Rys. 5. Konstrukcyjny przykład budowy osiowego węzła zestawu dla kolejowej komunikacji przestawczej

Łożyskowy korpus rolki obcego obrzeża 2 najkorzystniej powinien pozostać pod ramą pojazdu nieusprężynowany, podobnie jak koło biegowe 1, przy czym w kierunku pionowym powinien być połączony na przykład z korpusem $L$ łożyska osi zestawu.

\section{Mechanizm rozsuwania obrzeży rolkowych}

Na rysunkach 6 i 7 przykładowo pokazano zasadę mechanicznego rozsuwania obrzeży rolkowych.

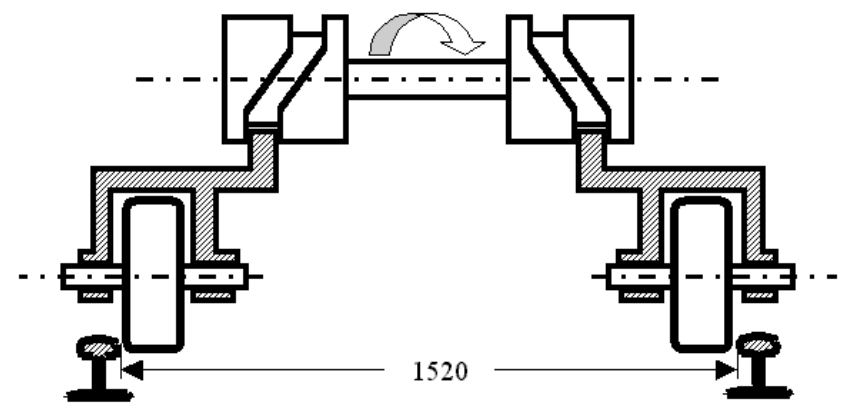

Rys. 6. Zasada rozsuwania i ryglowania obcych obrzeży rolkowych w krzywkowym przykładzie wykonania; położenie w torze $1520 \mathrm{~mm}$

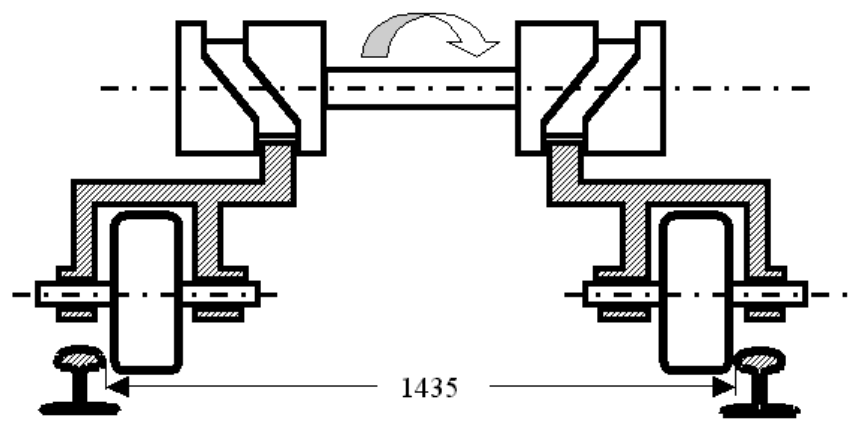

Rys. 7. Zasada rozsuwania i ryglowania obcych obrzeży rolkowych w krzywkowym przykładzie wykonania; położenie w torze $1435 \mathrm{~mm}$ 


\section{Aspekt eksploatacyjny}

Poważnym atutem proponowanego rozwiązania jest prostota reprofilacji zarysu współpracy zestawu z torem. Zgodnie z rysunkami 3 i 5 rolka 2 ma średnicę znacznie mniejszą niż koło 1 zestawu, ma zarys symetryczny i może być przekładana na drugą stronę. Rolka obrzeża, jako niewielki element podwozia, może być wymieniana $\mathrm{z}$ kanału obsługowego w wagonowni. Jakkolwiek reprofilacja zarysu koła biegowego 1 wymaga zabiegów tradycyjnych, to jest przy tym znacznie bardziej materiałooszczędna niż w przypadku zarysu klasycznego z obrzeżem własnym. Odpowiednie ilustracje porównawcze przedstawiono na rys. 8 i 9.

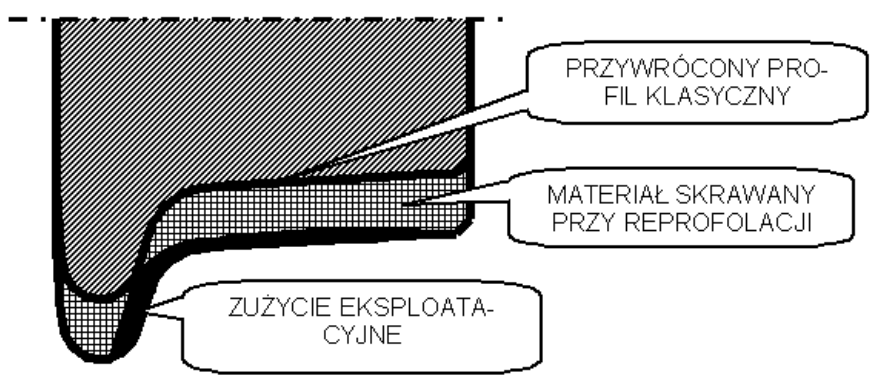

Rys. 8. Materiał skrawany podczas reprofilacji klasycznego koła pojazdu szynowego

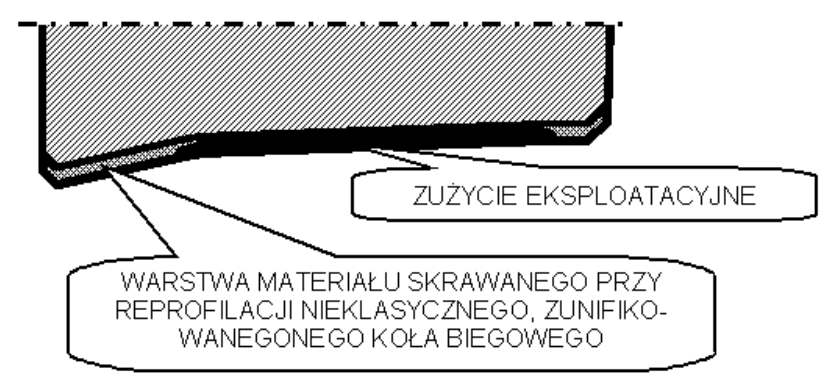

Rys. 9. Materiał skrawany podczas reprofilacji nieklasycznego koła bezobrzeżowego

\section{Podsumowanie}

Zaprezentowana koncepcja układu biegowego, dzięki swej technicznej prostocie, otwiera możliwość łatwego rozwiązania komunikacji wschód-zachód dzięki następującym atrybutom:

- zaprezentowane rozwiązanie techniczne jest odpowiednie zarówno dla wagonów jak też lokomotyw oraz innych pojazdów trakcyjnych;

- zaprezentowane rozwiązanie jest odpowiednie dla stosowanych hamulców kolejowych, zarówno klockowych jak i tarczowych;

- zaprezentowane rozwiązanie pozwala na znaczne obniżenie kosztów reprofilacji zarysu kół nośnych;
- zastosowanie trakcyjnych kół nośnych bez obrzeży zostało wypróbowane przez wiele dziesięcioleci w taborowej technice parowozów pięcioosiowych, gdzie środkowy zestaw był pozbawiony obrzeża, zaś prowadzenie parowozu $\mathrm{w}$ torze było powierzone obrzeżom nabiegających zestawów krańcowych;

- boczne siły prowadzące przenoszone są na ramę pojazdu poprzez osiowe łożyska i prowadniki nośnych zestawów kołowych podobnie jak w rozwiązaniach tradycyjnych;

- poszerzone pierścienie biegowe kół nośnych swobodnie mieszczą się w tradycyjnej skrajni taboru;

- zespoły obcych obrzeży rolkowych są relatywnie niedrogie i moga być łatwo dozorowane oraz wymieniane $\mathrm{w}$ wagonowniach i lokomotywowniach $\mathrm{z}$ kanałów przeglądowych.

\section{Lit e r a tura}

[1] Zeng J., Guan Q., H., Study on flange climb derailment criteria of a railway wheelset, Vehicle System Dynamics, 2008, Vol. 46, No. 3, s. 239-251.

[2] Madej J., Medwid M., Merkisz J., Stawecki W., Zestaw kót biegowych z obcymi obrzeżami rolkowymi, Zgłoszenie patentowe.

[3] Madej J., Medwid M., Merkisz J., Stawecki $W$., Zestaw kót biegowych z obcymi obrzeżami rolkowymi dla systemu przestawczego o zmiennej szerokości toru kolejowego 1435-1520, Zgloszenie patentowe. 